\title{
Analysis of E-Government Outsourcing
}

\author{
Bo Yang, Qian Li and Meiyun Zuo \\ School of Information, Renmin University of China, Beijing 100872, P.R. China \\ Yangbo_ruc@126.com linda_ruc@yahoo.com.cn zuomeiyun@263.net
}

\begin{abstract}
E-government outsourcing enables government to be relieved from IT system construction and maintenance, and concentrate on their management affairs, obtaining lower costs, more advanced technology, and less personnel demands additionally. This paper analyzes the e-government outsourcing according to types, advantages, risks, process and crucial factors, which gives suggestions on the cooperation between government departments and vendors, and contributes to the further healthy development of e-government outsourcing.
\end{abstract}

Keywords: E-government, Outsourcing, E-government outsourcing

\section{INTRODUCTION}

In recent years, China has made rapid development of e-government, with a total of over 10,000 websites at all levels of government departments. The focus in egovernment is transferring from system construction to application, while more urgent needs from system operation, management and maintenance are put forward [1]. In order to put main attentions on core business, e-government outsourcing has become an important measure to reduce the pressures from cost, technical, as well as personnel. E-government outsourcing, as a special form of IT outsourcing, is an optional IT system management mode for government departments, which means software and services about e-government, including system construction, day-to-day operation and maintenance and related services, are totally or partly executed by professional vendors.

This paper will analyze the status of Chinese e-government outsourcing according to its present situation, types, advantages, risks, process and crucial factors.

\section{PRESENT SITUATION OF E-GOVERNMENT OUTSOURCING}

E-government outsourcing is widely applied among many developed countries and regions. For example, learning from commercial users, U.S. government departments, ranging from federal agencies, state governments to municipalities, generally employ IT professional companies to take charge of their IT services

Please use the following format when citing this chapter:

Yang, B., Li, Q., Zuo, M., 2007, in IFIP International Federation for Information Processing, Volume 255, Research and Practical Issues of Enterprise Information Systems II Volume 2, eds. L. Xu, Tjoa A., Chaudhry S. (Boston: Springer), pp. 1191-1195. 
including application system, desktop systems, LAN and WAN management [2]. In Hong Kong's development process of e-government, system constructions and services have been implemented in outsourcing model [1].

China has also made many useful attempts in outsourcing of e-government, and accumulated some experiences. Among more than 200 e-government systems in Beijing, most projects are completed in the way of outsourcing through commission or bidding.

\section{TYPES, ADVANTAGES AND RISKS OF E-GOVERNMENT OUTSOURCING}

Distinguishing from other outsourcing projects, e-government outsourcing has some characters, such as larger project scale, combination of technology, application, and management, higher probability of process change, higher security level, great project uncertainty and complexity, requirements of long-term and stable services.

\subsection{Types of E-government Outsourcing}

Outsourcing work can be divided into project-type work and process-type work [3]. According to the contents, e-government outsourcing can be classified into the system construction outsourcing (project in nature) and maintenance outsourcing (process in nature).

Moreover, due to the cooperation relationships between governments and service vendors, e-government outsourcing projects can be divided into market-based, partnership, and intermediate types [3].

\subsection{Advantages of E-government Outsourcing}

The rapid development of e-government outsourcing is mainly due to three reasons as follows. The first one is cost factor. Outsourcing vendors generally have the advantage of scale economics while offering professional services, which means they can provide better service at lower cost. Another one is technical factor. Outsourcing enable government departments make use of necessary technology without making additional investments. The last one is personnel factor. The lack of qualified personnel for system construction and operation is very popular in governments. In spite of that, with the use of external personnel through outsourcing projects, government departments are able to solve the problem quite well.

Governments commonly benefit from e-government outsourcing in the following aspects: access to advanced technologies, meeting the demands of senior technical staffs, flexibility in choosing appropriate technology, flexible cash flow management, costs control and saving, as well as optimization of resources allocation. 


\subsection{Risks of E-government Outsourcing}

Thereupon e-government outsourcing burdens significant risks, including deficit spending risks, security risks, service failure risks, and the risks of losing quality control of service or management flexibility [4]. As a result, control of the risks in outsourcing should be severe and emphasized, which involves cautious decisions making on outsourcing, the selection of suitable vendors, reinforcing the terms of the contracts, setting a reasonable duration for projects, appropriate restrictions on vendors' speculation, and the strict business relationships management.

\section{THE PROCESS OF E-GOVERNMENT OUTSOURCING}

E-government outsourcing process is consisted of three consecutive stages, including e-government outsourcing decision-making, vendor selection, and project management. In the whole process, government departments should consider whether outsourcing or not, what the criteria is when choosing vendors, and make the decision on a long or short term outsourcing agreement, as well as how to prevent the risks and monitor vendors. All the process and relative key factors will be analyzed as follows:

\subsection{E-government Outsourcing Decision-making}

To identify whether outsourcing is needed or not, five issues are to be thought about. At first, the purpose and benefits of outsourcing must be clear, with a detailed feasibility analysis. Secondly, it must be recognized whether or not the outsourcing projects are related to core operations and business secrets. In the third aspect, the quality of vendors needs to be estimated, because the essence of outsourcing is to use the advantages of vendors. Fourthly, the government departments' abilities to effectively manage outsourcing as well as control complicated risks have to be evaluated to guarantee the projects' successful operation. Last but not least, the measures should be taken into account when outsourcing contracts expire or fail, including how to recover the projects, to facilitate the replacement of outsourcing vendors, and to renew the contracts if needed.

\subsection{Vendor Selection}

In regard to the vendors' selection, five other problems should be considered. 1) Whether the vendors have a well-known reputation, technology and knowledge about e-government process. 2) Whether the vendors are experienced in e-government projects construction and maintenance, with background of similar projects. 3) Whether the vendors are willing to modify their standard practice to meet the particular operational and financial needs of e-government projects in a flexible contract which could be amended by the government side. 4) Whether crucial qualified human resources from the vendors can be ensured by contracts, and whether the government departments have the authority to select staffs from candidates. 5) 
Whether there is good communication and culture atmosphere integration between vendors and governments.

\subsection{E-government Outsourcing Management}

The crucial stage in outsourcing projection's successful implement is the vendors' management. E-government outsourcing doesn't mean leave all IT services to vendors, but should retain a small crucial portion of management in departments. Staffs are assigned to be responsible for managing the relationships with vendors, supervision and approval of vendors' technical decision, accumulating outsourcing experience, developing future outsourcing decisions, negotiating outsourcing contracts, as well as developing e-government strategies accordant with the evolution of the government's overall goals.

\section{CRUCIAL FACTORS OF E-GOVERNMENT OUTSOURCING SUCCESS}

\subsection{Type of E-government Outsourcing}

In e-government outsourcing field, for system constructions, it's more appropriate to establish market-based type projects in complete contracts. While for system maintenance, which contain large number of uncertain factors, things become more complex. Long-term partnership-based type projects should be carried out on the basic of contracts lasting 5-10 years, which is an efficient way to ensure the asset specificity investment, sharing risks and benefits between both sides.

\subsection{Contracts}

Precise and detailed contracts should be made on vendors' responsibility, service standard and price, which are also the basis of evaluation for vendors. In the perfect contracts, vendors' income is linked with the level of service, and rules of punishments are established according to the service too, which are the basis for resolving the disputes during the outsourcing process. Otherwise, once dispute arises, without the corresponding contract agreement, it will induce huge lost to both sides. On the other side, perfect outsourcing contracts also maintain a certain degree of flexibility to respond to business and technology changes brought by the uncertainty, which can not be completely avoided, so that it's necessary to formulate appropriate rules in contracts to deal with controversy and uncertainty. 


\subsection{Control of Outsourcing Vendors}

In e-government outsourcing, the control of vendors is composed of price control, authority control, and trust control, which correspond to specific management mechanisms respectively [5]. E-government outsourcing is the combination of three mechanisms above, meanwhile in different outsourcing relationships, mechanisms have corresponding emphasis. For example, the rewards and punishments in contracts belong to price control mechanism; authority control regulars the approval of changes and reporting systems; and the evaluation of outsourcing services, as well as the priority right to sign contracts for the next contract, are adjusted by trust control mechanism.

\section{CONCLUSIONS}

This paper gives detailed and comprehensive analyzes about the types, advantages, risks, process, and crucial factors of e-government outsourcing. It is concluded that government departments should be concerned with e-government outsourcing process in terms of decision-making, vendor selection, and project management, with some factors being noticed, such as type of e-government outsourcing, contracts, and control of outsourcing vendors.

In conclusion, e-government outsourcing is becoming an inevitable trend in public affairs management. E-government outsourcing is becoming an optimal way for efficient service-oriented government.

\section{ACKNOWLEDGEMENTS}

This paper is supported by Beijing Natural Science Foundation, No. 9073015.

\section{REFERENCES}

1. L. Qiao, Study of E-government Outsourcing Model in Beijing, Report of Beijing Informationization Office (2006).

2. M. Cheng, L. Xu, and Y. Jin, IT outsourcing service and the E-government maintenance patterns of American, Information Network. Number 6, pp.28-30, (2003).

3. R. Klepper and W.O. Jones, Outsourcing Information Technology, Systems \& Services (Prentice Hall: Upper Saddle River, New Jersey, 1997), pp.160-170.

4. M.J. Earl, The Risk of Outsourcing IT, Sloan Management Review. Volume 37, Number 3, pp.26-32, (1996).

5. J.L. Bradach and R. Eccles. Price, Authority, and Trust, Annual Review of Sociology. Volume 15, pp.97-118, (1989). 